\title{
Methane Extraction from Abandoned Mines by Surface Vertical Wells: A Case Study in China
}

\author{
Shengyong Hu $\mathbb{D},{ }^{1,2}$ Ao Zhang, ${ }^{1}$ Guorui Feng $\mathbb{D}^{1,2}$ Xiangqian Guo, ${ }^{3}$ Xuyang Miu, \\ Chao Li, ${ }^{3}$ Dandan Han, ${ }^{1}$ Jin Wang, ${ }^{1}$ and Lixun Kang ${ }^{1,2}$ \\ ${ }^{1}$ College of Mining Engineering, Taiyuan University of Technology, Taiyuan 030024, China \\ ${ }^{2}$ Green Mining Engineering Technology Research Center of Shanxi Province, Taiyuan 030024, China \\ ${ }^{3}$ State Key Laboratory of Coal and CBM Co-Mining, Jincheng 048006, China \\ Correspondence should be addressed to Guorui Feng; fgrhsy@163.com
}

Received 25 October 2017; Revised 27 December 2017; Accepted 5 February 2018; Published 1 March 2018

Academic Editor: Egor Dontsov

Copyright (C) 2018 Shengyong Hu et al. This is an open access article distributed under the Creative Commons Attribution License, which permits unrestricted use, distribution, and reproduction in any medium, provided the original work is properly cited.

\begin{abstract}
Considerable methane resources exist in abandoned coal mines. However, methane extraction from abandoned mines in China is still in the exploratory stage. This study presents technologies and engineering practices suitable for the extraction of gob methane from abandoned mines using surface vertical wells, including methane drainage systems, well bottom locations, and an intermittent drainage method. Seven surface wells in the Yongan abandoned mine in China were selected for gob methane extraction. Field results showed that the methane volumetric flow rate of a well whose bottom was close to the gob bottom was 2.5 times greater than that of a well with a bottom located in the gob fractured zone. Moreover, intermittent extraction can enable a well to extract methane cyclically at a high volumetric flow rate. A well drilled mistakenly into a coal pillar can be reused through hydraulic fracturing. The overall maximum methane volumetric flow rate, average concentration, and extraction span were $210 \mathrm{~m}^{3} / \mathrm{h}, 83 \%$, and 1100 days, respectively.
\end{abstract}

\section{Introduction}

Coal mines are abandoned when they complete their useful economic life, and abandoned underground mines can be found in every country that has coal resources [1]. The UK has 900 abandoned mines, of which approximately 400 leak methane into the atmosphere [2]. Europe, Ukraine, and Russia also have many abandoned mines [1]. In China, Shanxi Province alone has more than 4700 abandoned mines, with methane reserves of approximately 3 billion $\mathrm{m}^{3}$ [3]. Methane in abandoned mines can create various environmental, health, safety, and economic concerns. For example, methane accumulated in abandoned mine gobs can leak out to the surface through cracks [4]. Therefore, it is necessary to extract abandoned mine methane, and this has been successfully done in the UK, Czech Republic, USA, Germany, France, and China [5].

Many studies have focused on using surface wells for stress-relief methane drainage to release the methane pressure that accumulates in gobs or coal seams during mining. Sang et al. [6] summarized current engineering practice and technology for stress-relief methane drainage with surface vertical wells in China. Sun et al. [7] studied deformation of surface well casings. Sun et al. [8] developed a shear deformation fracture model to study the well casing displacement that occurs as the working face advances. Schatzel et al. [9] investigated the effects of reservoir conditions and longwall panel response during mining on gob gas well performance. Guo et al. [10] developed a conceptual model to provide simple practical guidance for horizontal methane drainage design. Karacan [11] assessed the production performance of gob gas ventholes drilled along wall panels. Zhang et al. [12] analyzed the total gas flow rates from 29 surface gas ventholes located on four longwall faces for stress-relief methane drainage. Qin et al. [13] studied the optimal placement of abandoned gob wells. Qu et al. [14] conducted field trials at two Australian coal mines to evaluate the performance and effectiveness of surface directional boreholes. Liu et al. [15] investigated the impact of gob gas venthole drainage on gob gas flow. An et al. [16] applied 
TABLE 1: Coal seam occurrence in the Yongan mine.

\begin{tabular}{|c|c|c|c|c|c|c|}
\hline \multirow{2}{*}{$\begin{array}{l}\text { Coal seam } \\
\text { number }(\#)\end{array}$} & $\begin{array}{c}\text { Coal seam } \\
\text { thickness (m) }\end{array}$ & \multicolumn{2}{|c|}{ Coal seam distance $(\mathrm{m})$} & \multirow[b]{2}{*}{ Roof lithology } & \multirow[b]{2}{*}{ Floor lithology } & \multirow[b]{2}{*}{ Workability } \\
\hline & $\begin{array}{l}\text { Minimum- } \\
\text { maximum } \\
\text { Average }\end{array}$ & \multicolumn{2}{|c|}{$\begin{array}{c}\text { Minimum-maximum } \\
\text { Average }\end{array}$} & & & \\
\hline 3 & $\begin{array}{c}6.1-6.8 \\
6.3\end{array}$ & \multirow{3}{*}{$\begin{array}{l}42.6-63.2 \\
53.2\end{array}$} & & $\begin{array}{l}\text { Mudstone } \\
\text { Siltstone }\end{array}$ & $\begin{array}{l}\text { Mudstone } \\
\text { Siltstone }\end{array}$ & $\begin{array}{c}\text { Completely } \\
\text { minable }\end{array}$ \\
\hline 9 & $\begin{array}{c}0.3-1.0 \\
0.6\end{array}$ & & \multirow{2}{*}{$\begin{array}{c}21.0-34.1 \\
28.1\end{array}$} & $\begin{array}{l}\text { Mudstone } \\
\text { Siltstone }\end{array}$ & $\begin{array}{l}\text { Mudstone } \\
\text { Siltstone }\end{array}$ & $\begin{array}{l}\text { Partially } \\
\text { minable }\end{array}$ \\
\hline 15 & $\begin{array}{c}2.4-4.0 \\
3.0\end{array}$ & & & Limestone & $\begin{array}{l}\text { Mudstone } \\
\text { Siltstone }\end{array}$ & $\begin{array}{l}\text { Partially } \\
\text { minable }\end{array}$ \\
\hline
\end{tabular}

directional boreholes for methane drainage in adjacent seams during mining. These studies have all focused primarily on the efficient extraction of stress-relief methane with surface wells. Currently, the studies of methane extraction from abandoned mines in China are still at an exploratory stage [3].

Some studies about methane emissions and extraction of abandoned mines have also been conducted. The EPA [17] proposed a formula to calculate the methane emission rate from abandoned coal mines in the United States. Leifer and Wilson [18] measured the gas seepage at a repeatedly abandoned well in Nearshore Summerland, California. Palchik [19] analyzed the data of time-dependent methane emission and estimated the gas flow rate parameters and cumulative production of the wells drilled to partly flooded abandoned workings at shallow depth by exponential decline analysis. Karacan [1] studied methane extraction characteristics of abandoned mines by modeling study and data analysis. All of these studies can provide theoretical guidance for methane extraction from abandoned mines. However, existing studies did not consider some unique characteristics of abandoned mines in China, such as residual methane pressure, overlying strata development, and aquifers. These characteristics will directly affect the arrangements of the methane drainage system, the well bottom location, and the methane drainage adjustment used for the methane drainage of abandoned mines $[5,20]$. It is essential to propose some technologies, especially considering these unique characteristics.

This paper presents and describes in detail the technologies of the methane extraction of abandoned mines using surface wells, especially considering those unique characteristics of abandoned mines in China. These technologies were then verified with a field engineering trial at the Yongan abandoned mine in China.

\section{Description of the Yongan Abandoned Mine}

The Yongan abandoned mine is a gassy coal mine in China that has been completely closed since November 2011. It stretches from south to north and has a length of $5.2 \mathrm{~km}$ and width of $2.8 \mathrm{~km}$, covering a total area of $6.5101 \mathrm{~km}^{2}$. Before its closure, the mine produced 0.9 million tons of anthracite coal annually. The average original methane pressure and total methane content were $1.08 \mathrm{MPa}$ and $18 \mathrm{~m}^{3} / \mathrm{t}$, respectively.
The Yongan mine is located in the southern part of the Qinshui Coalfield, which is in an area with low mountains and hills; the maximum relative elevation difference of the terrain is approximately $283 \mathrm{~m}$. The mine has a moderate hydrogeological type, and the groundwater storage is dominated by diving. The aquifer thickness is small and has a shallow water table depth.

The minable coal seams in the Yongan mine were coal seam \#3 in the lower group of the Shanxi Formation and coal seams \#9 and \#15 in the Upper Carboniferous Taiyuan Formation. As summarized in Table 1, coal seam \#3 is nearly horizontal and is stable in the mine area. This coal seam is $6.1-6.8 \mathrm{~m}$ thick, with an average thickness of $6.3 \mathrm{~m}$. The immediate roof of coal seam \#3 is approximately $5.3 \mathrm{~m}$ thick and is composed primarily of mudstone and siltstone. The floor is mudstone and siltstone and has a thickness of approximately $1.8 \mathrm{~m}$. Coal seam \#9 is unstable, while coal seam \#15 is stable and minable in the entire mine area.

Historically, coal seam \#3 of the Yongan mine was mined using the longwall mining method at a mining depth of between $320 \mathrm{~m}$ and $360 \mathrm{~m}$. The distribution of coal mine gobs formed within the Yongan mine range is shown in Figure 1. Six surface wells have been drilled to extract the methane in these abandoned gobs, and their locations are also shown in Figure 1.

\section{Methane Drainage Trials at the Abandoned Mine}

3.1. Methane Drainage System. The methane drainage system consists of the borehole camera detection method (Figure 2), a configuration of wellbore (Figure 3), and a surface methane drainage system (Figure 4). During the dynamic and continuous mining process, the stresses in the overlying strata vary continuously, which can significantly affect the stability of the surface vertical wells located in the overlying strata [6]. Therefore, structural designs for these surface wells mainly consider the effects of mining stress $[7,8,21,22]$. However, in an abandoned mine, the mining stress has stabilized, and thus water influx from aquifers into the abandoned gobs is the most significant problem. The drilled wells pass through aquifers to reach the gobs, which can allow underground water to flow into the gobs, significantly affecting the gob methane flow to the wells. 


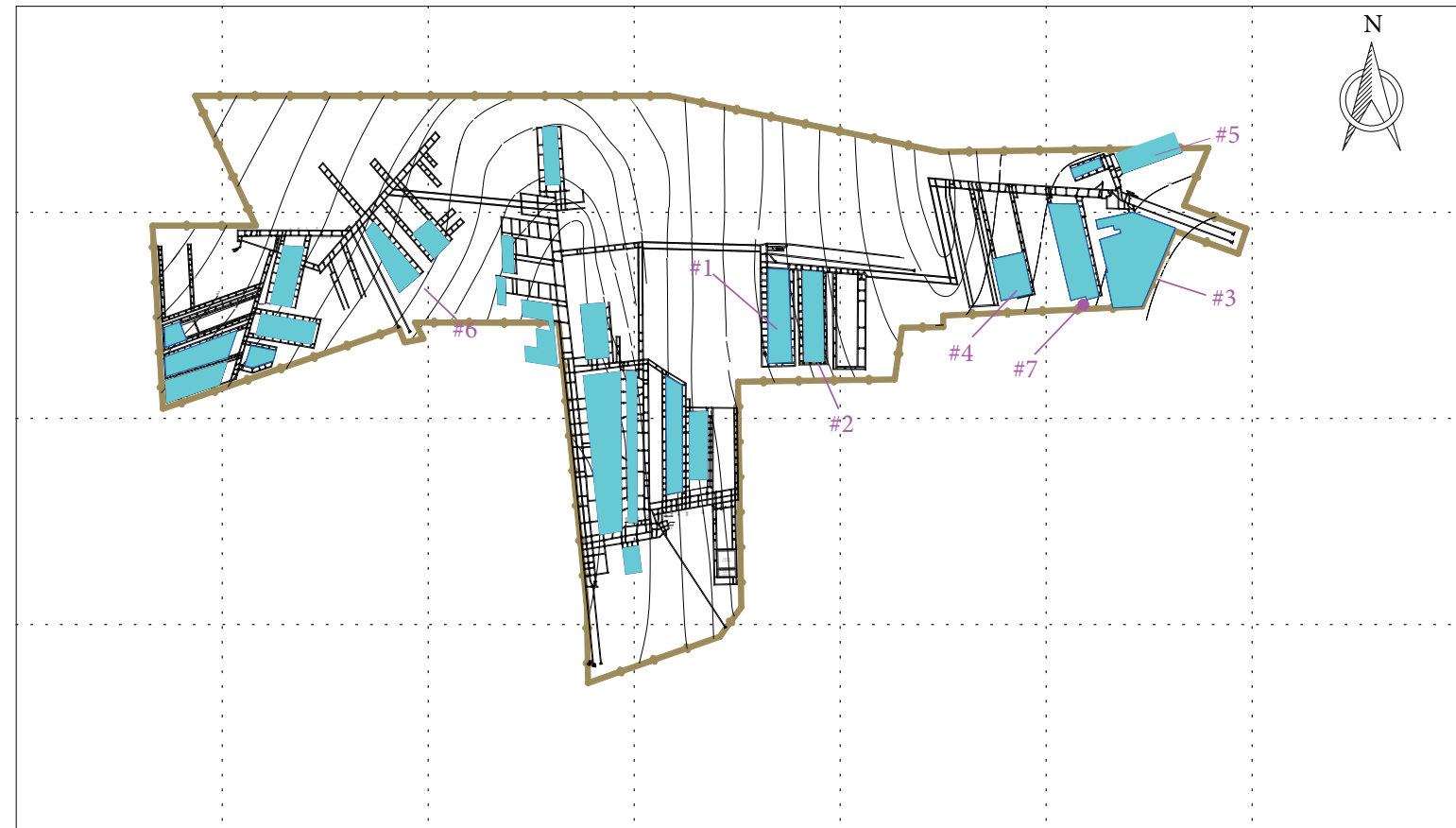

\footnotetext{
- Surface well

$\overline{7 \Gamma}$ Roadway

Gob area
}

_ Coal mine boundary

Contour line of coal seam floor

Figure 1: Abandoned gob distribution within the Yongan mine range.
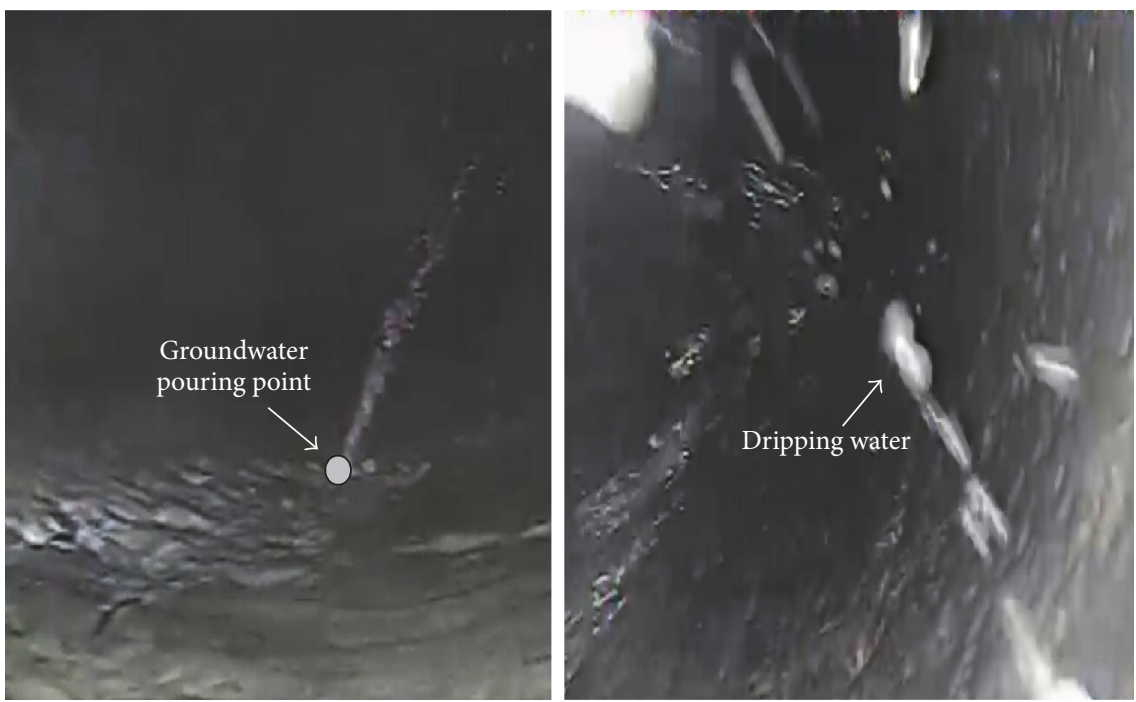

FIGURE 2: Borehole camera images along the drilled wells.

A borehole camera detection method [23] was used to detect aquifers above the abandoned gobs in the Yongan mine. Figure 2 shows images from the borehole at well \#1 (shown in Figure 1). These images show an obvious point at which groundwater is pouring out of the well wall, indicating the location of an aquifer. The water from these points flows directly to the bottom of the drilled well. Thus, it is important that all aquifer positions are detected and sealed before the drilled wells reach the gobs.

When the gob has collapsed and the aquifers above the gob are sealed, the surface well used to drain the abandoned gob methane can be divided into three parts, as shown in Figure 3(a). In this case, the top part of the well is drilled through the topsoil overburden and enters the $10 \mathrm{~m}$ deep 


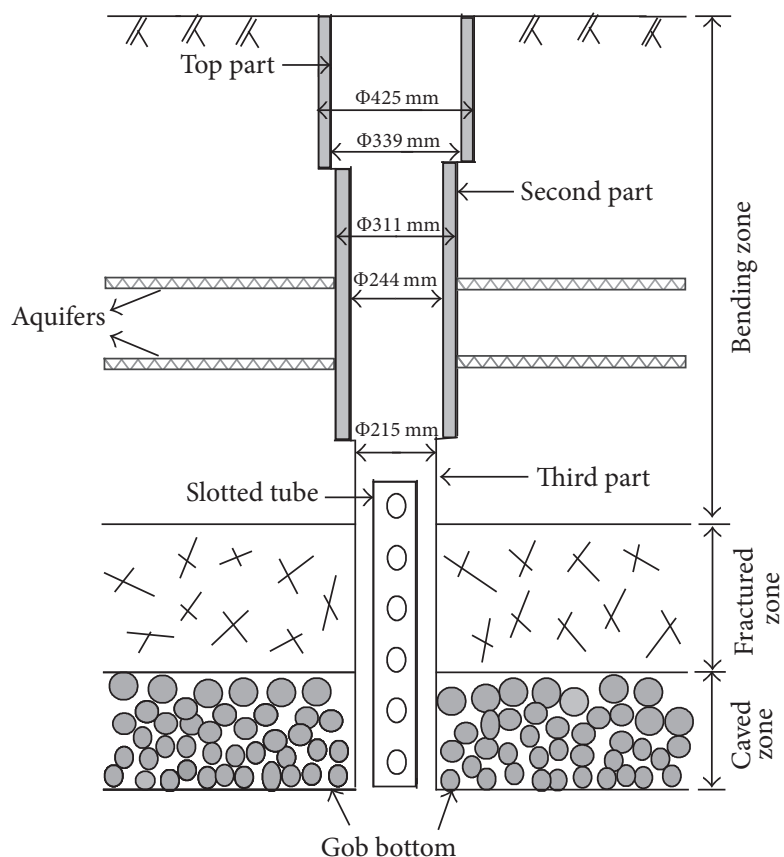

(a)

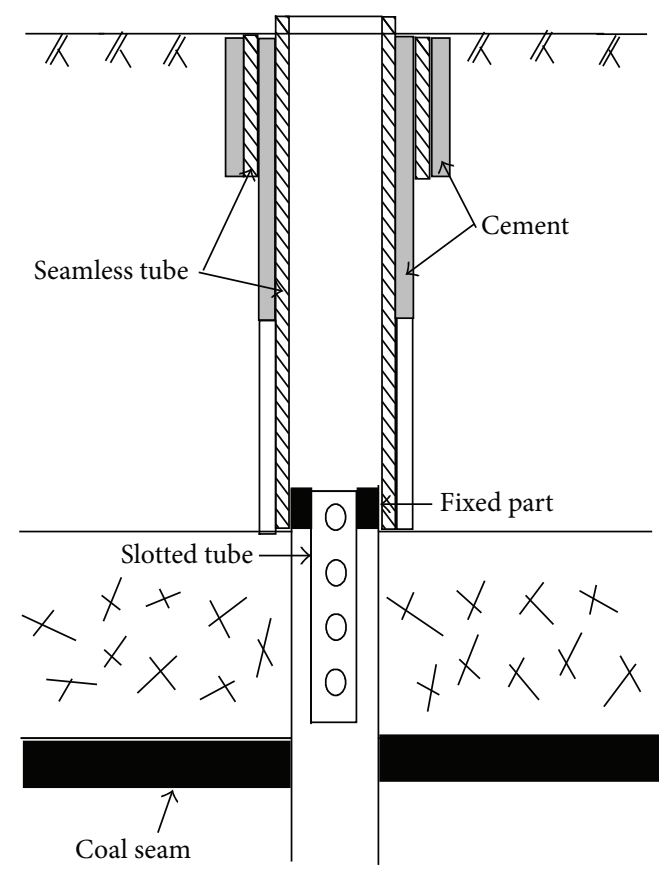

(b)

Figure 3: Sketch of two surface well structures: (a) surface well structure used in the Yongan mine area and (b) surface well structure used in the Chengzhuang mine area.

bedrock with a bore diameter of $425 \mathrm{~mm}$, followed by introduction of a $339 \mathrm{~mm}$ diameter seamless tube, which is fixed to the well wall with high-strength, low-density cement. The second part of the well is drilled with a $311 \mathrm{~mm}$ bore diameter through all detected aquifers, followed by introduction of a $244 \mathrm{~mm}$ diameter seamless tube, which is sealed against the aquifers with cement. Finally, the third part of the well is drilled into the lower gob with a $215 \mathrm{~mm}$ bore diameter, followed by a slotted tube, which is used in case a well collapse blocks airflow passage in the gob.

Adopting this type of wellbore configuration can improve the efficiency of draining the abandoned gobs and reduce construction costs of the surface vertical wells. This configuration accounts for sealing of the aquifers without the unnecessary fixation of slotted tubes in the abandoned boreholes shown in Figure 3(b) [20].

Based on the proposed wellbore configuration and the geological conditions at the Yongan mine, the surface methane drainage system shown in Figure 4 was used for methane extraction. This surface methane drainage system consists of a pressure gauge, wellhead gate valve, one-way valve, tailrace, flame arrester, solenoid valve, temperature sensor, methane concentration sensor, oxygen concentration sensor, vacuum negative pressure gauge, panel, water-ring vacuum pump, screw supercharger, flow meter, air collector, master valve, and gathering station.

The six wells were closed and sealed after drilling was completed, and then pressure gauges (Figure 4) were installed at the upper part of each well to monitor the residual methane pressure in the abandoned mine gobs, as shown in Figure 5. The pressure measured at those wells was only $0.002-0.020 \mathrm{MPa}$, which is much lower than the original methane pressure of 1.08 MPa. For comparison, the reported residual methane pressures at the Peyerimhoff abandoned mine in France and the Markham abandoned mine in England are between $0.050 \mathrm{MPa}$ and $0.102 \mathrm{MPa}$ [5].

The desorbed (released) methane in the gobs is extracted by utilizing the negative pressure at the well bottom produced by a water-ring vacuum pump. The methane is then pressurized to $0.2-0.3 \mathrm{MPa}$ with a screw supercharger and transported to the air collector and gathering station. The methane extraction parameters are monitored with the methane concentration sensor, oxygen concentration sensor, temperature sensor, vacuum negative pressure gauge, and flow meter. The panel control program modulates the solenoid valve to adjust the methane extraction pressure, which directly affects the methane extraction concentration and flow. Owing to the low residual methane pressure in the abandoned gobs, the methane extraction pressure must be set to a micropositive pressure or micronegative pressure in the range of -7 to $+2 \mathrm{kPa}$ to ensure the stability of the methane production.

3.2. Location of the Well Bottom. Figure 6 shows a sketch of various surface well bottom locations. It is generally accepted that a well location in the fractured zone near the caved zone is most effective for gob methane drainage as this location is enriched by gob stress-relief methane [6]. Surface Well $\mathrm{I}$, which has a well bottom located in the "O-ring" of the fractured zone, as shown in Figure 6, is typically used to drain the abandoned gob methane.

The methane flow in abandoned mine gobs can be described by Darcy's law [24]:

$$
u=-\frac{K_{p}}{\mu} \nabla P,
$$




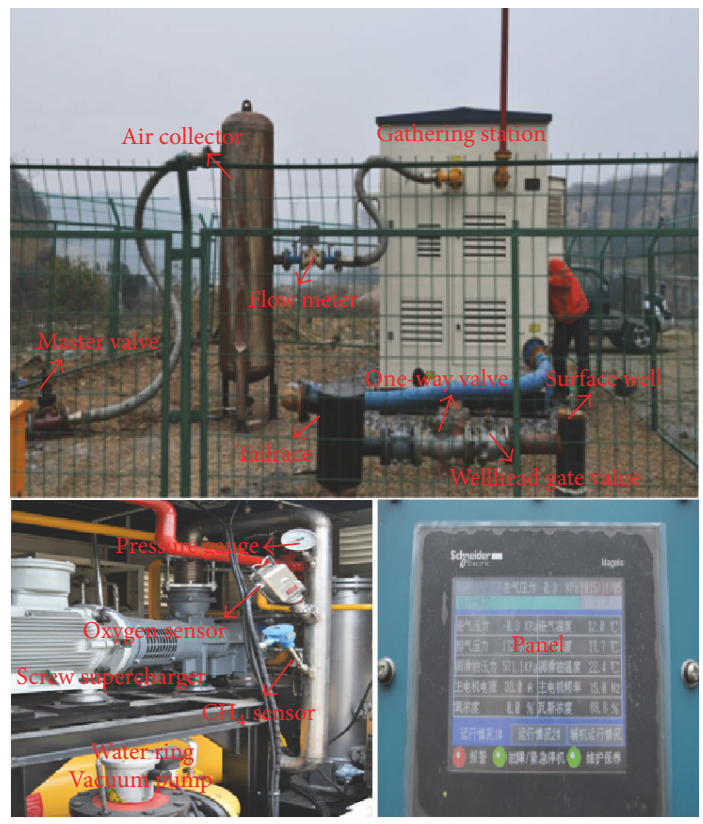

(a)

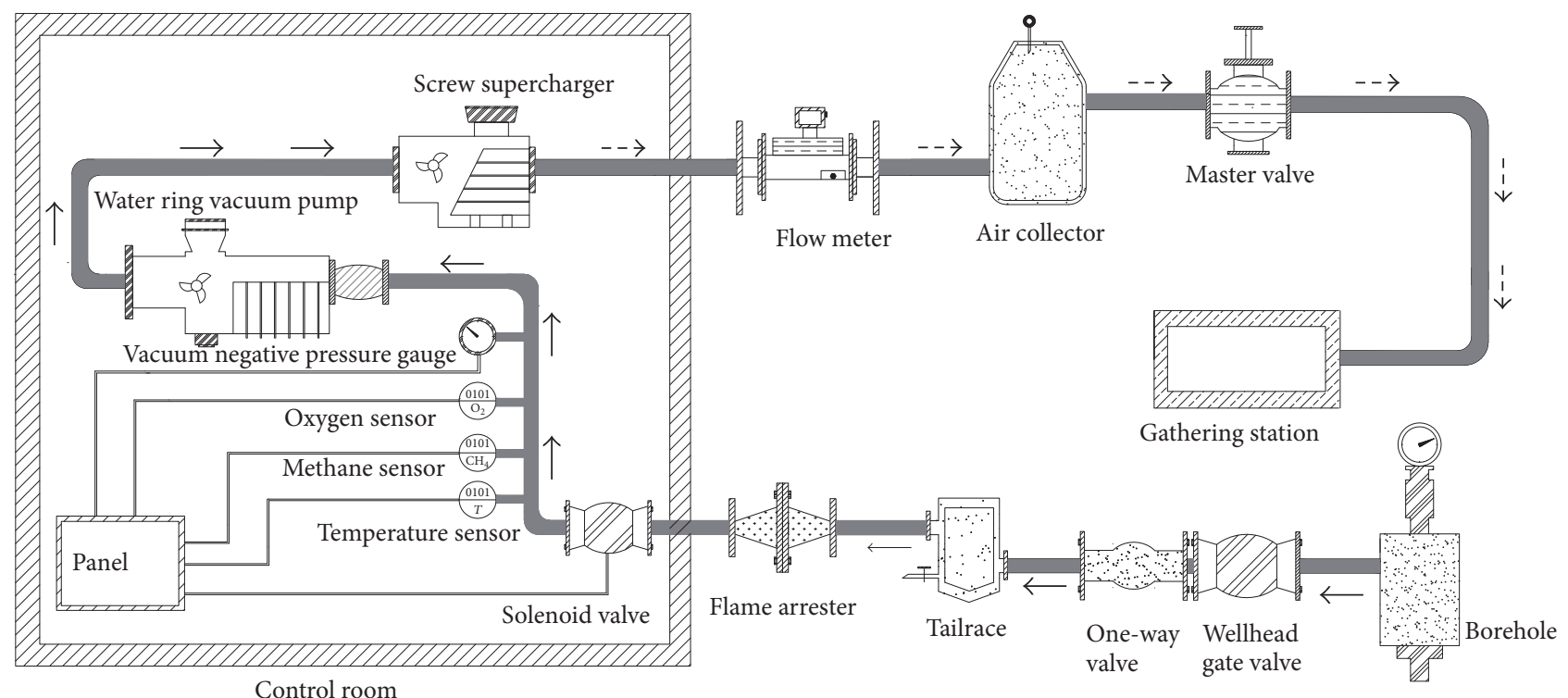

(b)

FIGURE 4: Surface methane drainage system: (a) physical image map and (b) schematic diagram.

where $u$ is the relative velocity between the fluid and the solid structure, $\mu$ is the dynamic viscosity of the fluid, $\nabla P$ is the pressure gradient that acts as the driving force for fluid flow through the porous media, and $K_{p}$ is the permeability.

Darcy's law indicates that Well I will only be suitable for use with a newly formed gob that has a relatively high residual methane pressure. There will be a relatively large pressure gradient between the lower area and the upper area of this type of gob after the free gob methane is extracted by the surface well, allowing the methane to flow easily into Well I.

However, the low methane pressure in an abandoned gob corresponds to a low negative pressure extraction, which means that Well I has a small effective extraction range. The gob methane cannot easily flow into that small range in a reasonable amount of time owing to the very low pressure gradient. Therefore, it is necessary to change the conventional well bottom position for use in abandoned mine gobs. Well II has a bottom located near the residual coal and the gob bottom and should be used for quick and efficient extraction of the desorbed methane from the residual coal.

Occasionally, incomplete or inaccurate abandoned gob information may lead to a well being mistakenly drilled into the coal pillar around a gob. Because of the poor permeability of the original coal seam in the Yongan mine, the methane drainage flow from this well was poor and 


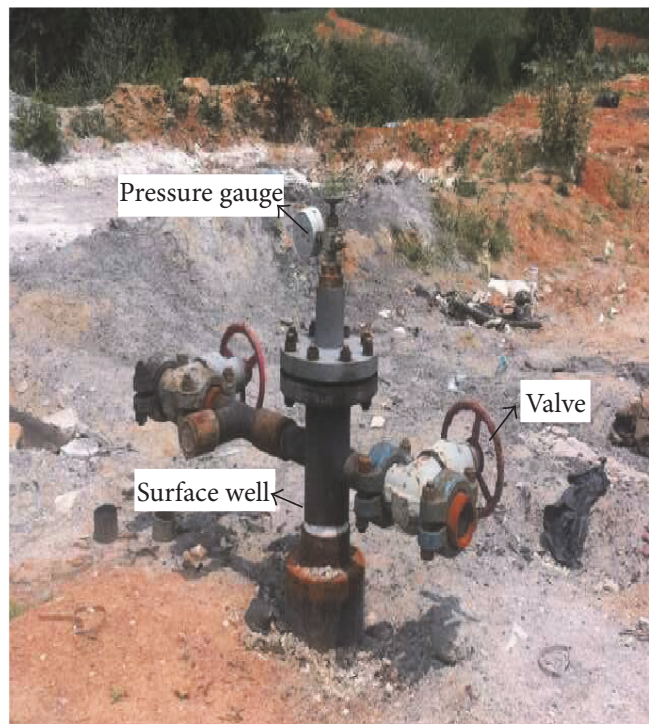

FIGURE 5: Setup for field measurement of residual methane pressure in abandoned mine gobs.

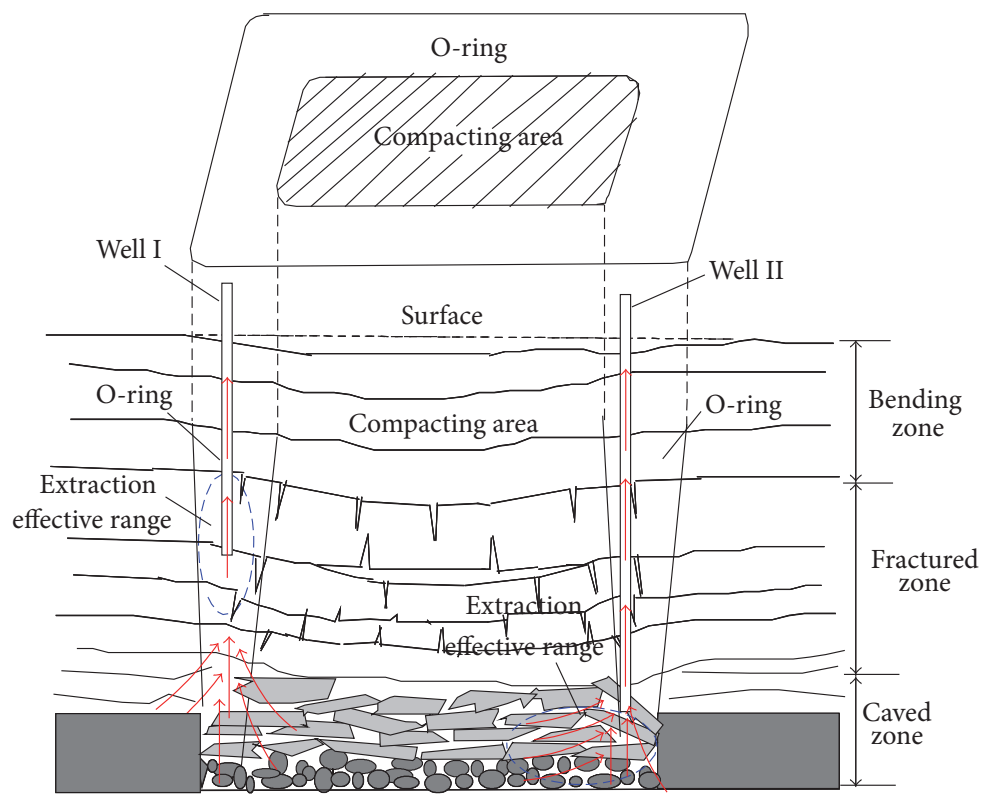

FIGURE 6: Sketch of different surface well bottom locations.

it had to be abandoned. Figure 7 shows that this well was mistakenly drilled into the coal pillar of coal seam \#3. To reuse this abandoned well, drilling should continue until the well penetrates coal seams \#9 and \#15 located below coal seam \#3. A hydraulic fracturing method [25-27] could then be used to increase the original permeability of the three coal seams and allow the abandoned well to be reused.

3.3. Intermittent Efficient Methane Drainage. The desorption rate of the residual coal in abandoned mine gobs initially decreases sharply with increasing desorption time, after which it decreases more gradually [19]. As a result, the methane pressure in the abandoned gob decreases as the gob methane is extracted. The free methane content can be obtained with Mariotte's law [28]:

$$
V_{g}=\frac{\phi_{r} p T_{0}}{p_{0} T Z}
$$

where $V_{g}$ is the free methane volume in the normal state $\left(\mathrm{m}^{3} / \mathrm{t}\right) ; \varphi_{r}$ is the residual pore volume $\left(\mathrm{m}^{3} / \mathrm{t}\right) ; p$ is the methane pressure $(\mathrm{MPa}) ; p_{0}$ and $T_{0}$ are the pressure in the normal state $(0.101325 \mathrm{MPa})$ and absolute temperature $(273 \mathrm{~K})$, respectively; $T$ is the reservoir temperature, which can be estimated by the depth; and $Z$ is the methane compressibility factor, which can be obtained from generalized compressibility charts. During methane drainage, the methane pressure in an 


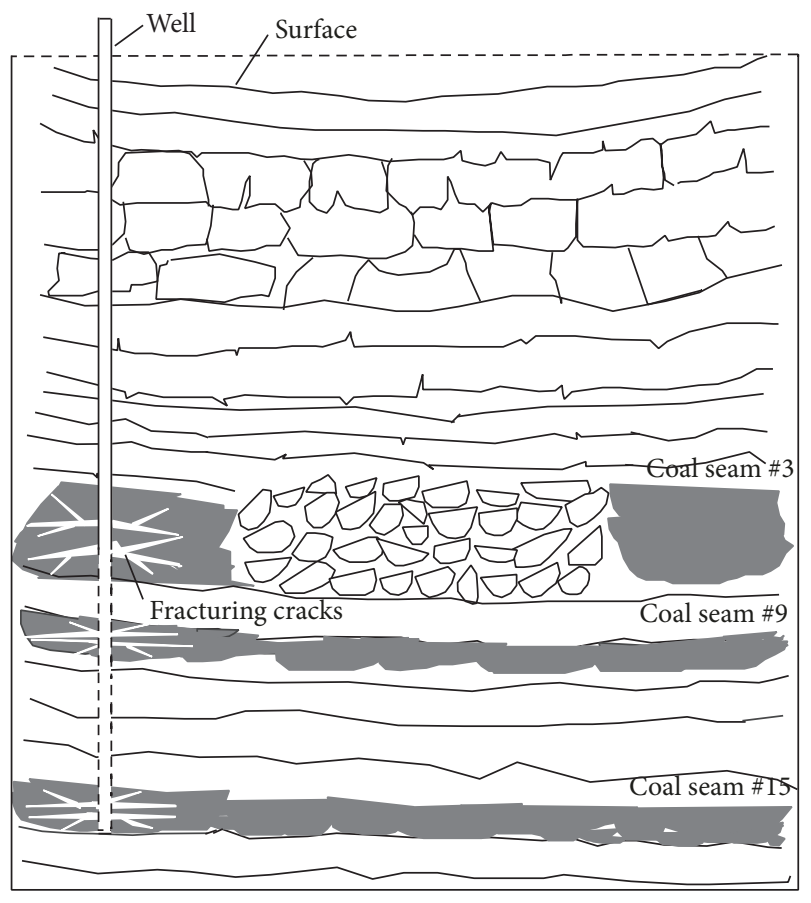

FIGURE 7: Schematic of the methane extraction through a coal pillar using hydraulic fracturing.

abandoned gob becomes relatively low, at which point the gob has a low free methane volume, as indicated by (2).

The adsorbed methane and desorbed methane in the coal are in a dynamic equilibrium. As the methane pressure successively decreases and increases, the coal will undergo corresponding successive desorption and adsorption processes. As the coal desorption rate and the free methane content decrease, the methane drainage flow will gradually decrease and become exhausted. At this point, it is advisable to cease drainage for a period to allow the methane in the coal pillar, roadway, or other gobs to gradually accumulate in the gob where the well is located; over time, the residual coal in this gob can thus gradually return to the initial methane pressure. When the methane extraction is restarted, the residual coal will undergo methane desorption at a relatively high rate again, enabling extraction of a high methane flow from the well. This technique could solve the problems of high energy consumption and low production efficiency that are experienced when the methane extraction flow of a well is low.

\section{Field Application Results}

As shown in Figure 1, wells \#1 and \#2 are located in adjacent gobs, which have similar geometrical and geological conditions. As a result, the two wells have similar gas adsorptions and flow conductivities. Moreover, the two wells have very similar well locations and methods of extraction. Therefore, wells \#1 and \#2 were selected to study the influence of the well bottom position on the methane production.

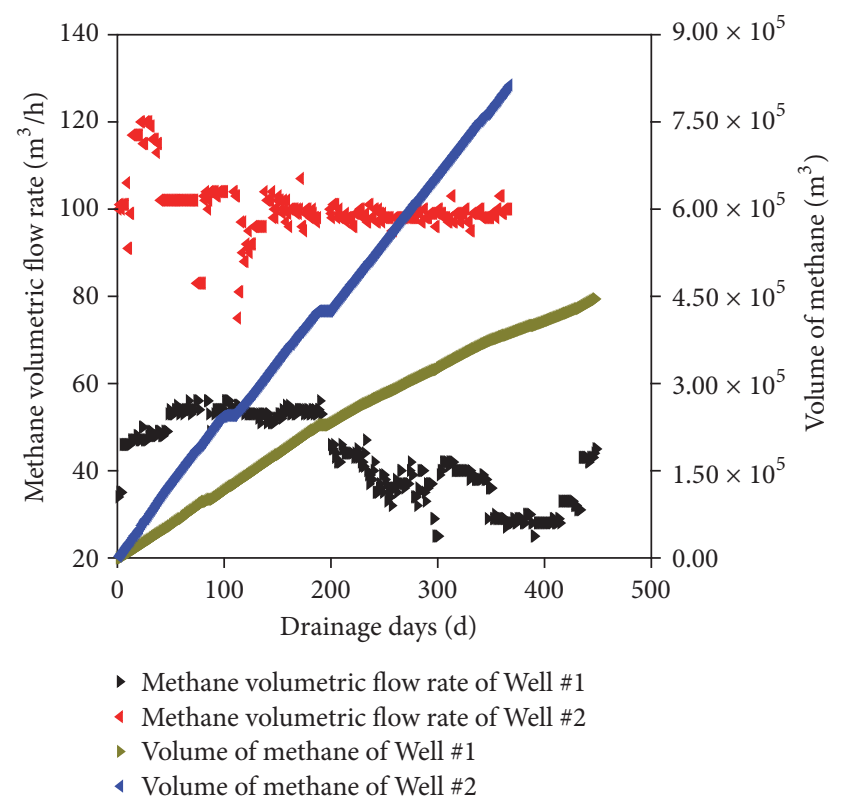

FIGURE 8: Comparison of methane extraction flow for different well locations.

The bottom of well \#1 is located in the gob fractured zone approximately $40 \mathrm{~m}$ above the roof of coal seam \#3, whereas the bottom of well \#2 is located approximately $5 \mathrm{~m}$ below the floor coal seam \#3. The methane volumetric flow rates and the methane volumes of the two wells are shown in Figure 8.

Figure 8 shows that there are some fluctuations for the initial methane volumetric flow rate, similar to the results obtained by Karacan (2015) [1], and then the overall trends of wells \#1 and \#2 are declining in the duration of the methane drainage, which are confirmed by EPA (2004) [17] and Palchik (2014) [19]. The average methane volumetric flow rate of well \#1 was only $40 \mathrm{~m}^{3} / \mathrm{h}$, whereas the average methane volumetric flow rate of well $\# 2$ was $100 \mathrm{~m}^{3} / \mathrm{h}$, or 2.5 times greater than that of well \#1. During the first 350 days of drainage, the methane volume in well \#1 was $4.0 \times 10^{5} \mathrm{~m}^{3}$, whereas the methane volume in well $\# 2$ was $7.5 \times 10^{5} \mathrm{~m}^{3}$, which is nearly two times that of well \#1. It is clear that methane extraction at well \#2 was much more effective than at well \#1. Therefore, it can be concluded that the methane extraction is better the closer the well bottom is to the bottom of the abandoned mine gob.

Well \#3, shown in Figure 1, was chosen to investigate the impact of intermittent extraction on methane production. Figure 9 shows that, over 80 days of extraction at well \#3, the methane volumetric flow rate decreased significantly from $325 \mathrm{~m}^{3} / \mathrm{h}$ to $130 \mathrm{~m}^{3} / \mathrm{h}$, indicating the near exhaustion of methane in the gob. At this point, well \#3 was closed for approximately 200 days to allow the methane from the surrounding gobs to flow into that gob, accumulating until the methane pressure returned to its original level.

When well \#3 resumed extraction, the methane volumetric flow rate was initially relatively $380 \mathrm{~m}^{3} / \mathrm{h}$ high, which decreased sharply to approximately $150 \mathrm{~m}^{3} / \mathrm{h} 140$ days later. 
TABLE 2: Representative methane extraction effect of surface wells in the abandoned mine.

\begin{tabular}{|c|c|c|c|c|}
\hline $\begin{array}{l}\text { Methane } \\
\text { extraction time }(\mathrm{d})\end{array}$ & Well number (\#) & $\begin{array}{c}\text { Average } \\
\text { concentration } \\
\text { Minimum } ~ \\
\text { maximum (\%) }\end{array}$ & $\begin{array}{l}\text { Average methane } \\
\text { flow rate } \\
\text { Minimum } ~ \\
\text { maximum }\left(\mathrm{m}^{3} / \mathrm{h}\right)\end{array}$ & $\begin{array}{c}\text { Cumulative } \\
\text { methane flow }\left(\mathrm{m}^{3}\right)\end{array}$ \\
\hline 1100 & 4 & $\begin{array}{c}81 \\
63 \sim 89\end{array}$ & $\begin{array}{c}76 \\
60 \sim 88\end{array}$ & $2.0 \times 10^{6}$ \\
\hline 663 & 5 & $\begin{array}{c}85 \\
79 \sim 95\end{array}$ & $\begin{array}{c}80 \\
63 \sim 88\end{array}$ & $8.3 \times 10^{5}$ \\
\hline 1016 & 6 & $\begin{array}{c}83 \\
77 \sim 95\end{array}$ & $\begin{array}{c}159 \\
139 \sim 210\end{array}$ & $4.4 \times 10^{6}$ \\
\hline
\end{tabular}

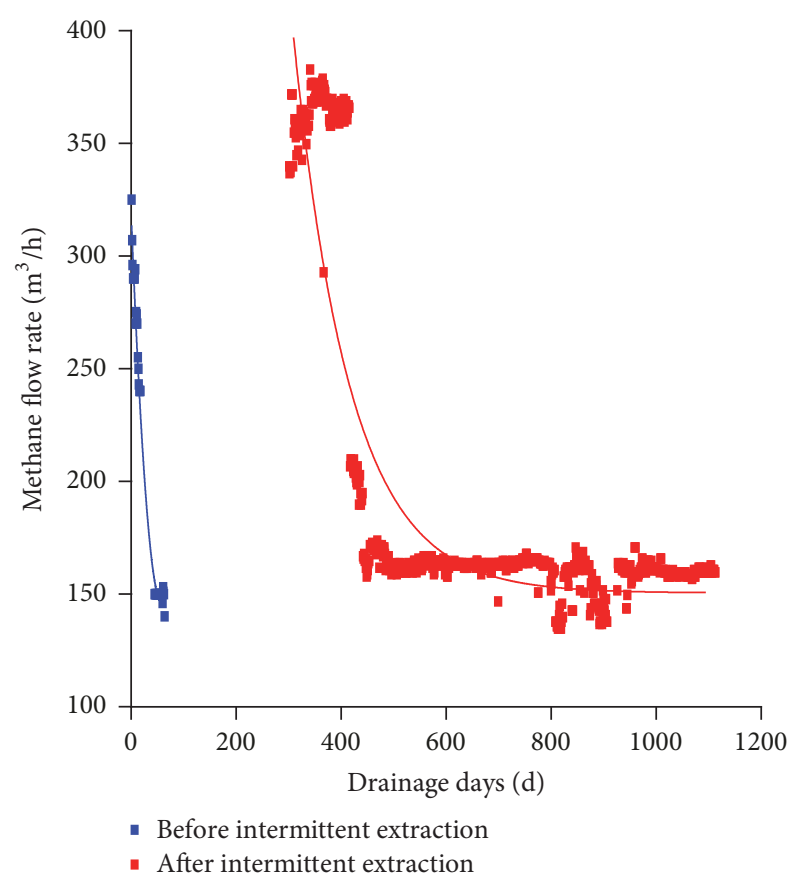

FIgURE 9: Methane extraction flows before and after intermittent extraction.

This suggests that the intermittent extraction method, that is, extraction-pause-extraction, can enable the well to continue extracting at a high methane volumetric flow rate and significantly reduce energy consumption, thereby improving the efficiency of the well.

Wells \#4, \#5, and \#6 have the structure illustrated in Figure 3 and used the extraction system illustrated in Figure 4; the methane extraction results are summarized in Table 2. The minimum methane volumetric flow rate was $60 \mathrm{~m}^{3} / \mathrm{h}$, the maximum was $210 \mathrm{~m}^{3} / \mathrm{h}$, the average methane concentration was $83 \%$, and the methane extraction time was 1100 days.

\section{Conclusions}

Abandoned mine methane can create various environmental, health, safety, and economic concerns. It is necessary to extract the methane from abandoned gobs, which can contain considerable methane resources. However, methane drainage from abandoned mines in China is still in the exploratory stage compared to the stress-relief methane extraction employed during mining. This study evaluates technologies and engineering practices for surface vertical wells that are different from those used in stress-relief methane extraction, including a methane drainage system, well bottom locations, and intermittent drainage.

Aquifer positions above abandoned gobs were detected and sealed before drilled wells entered the gobs. A single well drainage system was used to control the negative methane extraction pressure at micropositive or micronegative pressures of -7 to $+2 \mathrm{kPa}$ to ensure stability of methane production. Because of the low gob methane pressure and low extraction pressures, the optimal well location to efficiently extract methane from the residual coal in a reasonable amount of time was near the bottom of the gob. An intermittent extraction method, that is, extraction-pause-extraction, could be used to enable wells to resume methane extraction at high flow rates. For wells drilled into coal pillars around gobs, it was suggested that the drilling should continue downwards until it has penetrated all the coal seams, after which hydraulic fracturing can be used to improve the low permeability of these coal seams.

The average methane volumetric flow rate at a well whose bottom is close to the gob bottom is 2.5 times greater than that of a well located in the gob fractured zone. When the methane volumetric flow rate at a well exhibited a drastic decrease from $325 \mathrm{~m}^{3} / \mathrm{h}$ to $130 \mathrm{~m}^{3} / \mathrm{h}$, it was closed for approximately 200 days. When the well resumed extraction after this pause, the methane volumetric flow rate had returned to a relatively high $380 \mathrm{~m}^{3} / \mathrm{h}$. In addition, a well that had been mistakenly drilled into coal pillars could be reused using hydraulic fracturing. The overall maximum methane volumetric flow rate, average concentration, and extraction span were $210 \mathrm{~m}^{3} / \mathrm{h}, 83 \%$, and 1100 days, respectively, with the proposed well structure and methane extraction system.

\section{Conflicts of Interest}

The authors declare that they have no conflicts of interest.

\section{Acknowledgments}

This research was supported by the National Natural Science Foundation of China (51504160, 51574172), the Coalbed 
Methane Joint Research Foundation of Shanxi Province (2015012008), and the Joint Funds of the National Natural Science Foundation of China (U1710258, U1710121). This work is also a project funded by the innovative entrepreneurship projects for college students (CX090).

\section{References}

[1] C. Ö. Karacan, "Modeling and analysis of gas capture from sealed sections of abandoned coal mines," International Journal of Coal Geology, vol. 138, pp. 30-41, 2015.

[2] "Methane From Abandoned Coal Mines-A Solution for Controlling Emissions, DTI/Pub URN 04/933, 2004".

[3] Z.-P. Meng, X.-C. Shi, S.-S. Liu, Y.-D. Tian, and C. Li, "Evaluation model of CBM resources in abandoned coal mine and its application," Meitan Xuebao/Journal of the China Coal Society, vol. 41, no. 3, pp. 537-544, 2016.

[4] V. Palchik, "In situ study of intensity of weathering-induced fractures and methane emission to the atmosphere through these fractures," Engineering Geology, vol. 125, pp. 56-65, 2012.

[5] J.-Q. Shi, R. M. Rubio, and S. Durucan, "An improved voidresistance model for abandoned coal mine gas reservoirs," International Journal of Coal Geology, vol. 165, pp. 257-264, 2016.

[6] S. Sang, H. Xu, L. Fang, G. Li, and H. Huang, "Stress relief coalbed methane drainage by surface vertical wells in China," International Journal of Coal Geology, vol. 82, no. 3-4, pp. 196203, 2010.

[7] H. T. Sun, Y. R. Zheng, Q. T. Hu, and F. J. Liu, "Surface borehole casing coupling deformation mechanism," Journal of China Coal Society, vol. 36, pp. 823-829, 2011.

[8] H. T. Sun, F. J. Liu, and J. Zhang, "Shear deformation model on surface drilling and its spatial analysis," Journal of Mining and Safety Engineering, vol. 28, pp. 72-76, 2011.

[9] S. J. Schatzel, C. Ö. Karacan, H. Dougherty, and G. V. R. Goodman, "An analysis of reservoir conditions and responses in longwall panel overburden during mining and its effect on gob gas well performance," Engineering Geology, vol. 127, pp. 65-74, 2012.

[10] H. Guo, C. Todhunter, Q. Qu, and Z. Qin, “Longwall horizontal gas drainage through goaf pressure control," International Journal of Coal Geology, vol. 150-151, pp. 276-286, 2015.

[11] C. Ö. Karacan, "Analysis of gob gas venthole production performances for strata gas control in longwall mining," International Journal of Rock Mechanics and Mining Sciences, vol. 79, pp. 9-18, 2015.

[12] C. Zhang, S. Tu, Q. Bai, G. Yang, and L. Zhang, "Evaluating pressure-relief mining performances based on surface gas venthole extraction data in longwall coal mines," Journal of Natural Gas Science and Engineering, vol. 24, pp. 431-440, 2015.

[13] W. Qin, J. Xu, and G. Hu, "Optimization of abandoned gob methane drainage through well placement selection," Journal of Natural Gas Science and Engineering, vol. 25, pp. 148-158, 2015.

[14] Q. Qu, H. Guo, and M. Loney, "Analysis of longwall goaf gas drainage trials with surface directional boreholes," International Journal of Coal Geology, vol. 156, pp. 59-73, 2016.

[15] Y. Liu, S. Shao, X. Wang, L. Chang, G. Cui, and F. Zhou, "Gas flow analysis for the impact of gob gas ventholes on coalbed methane drainage from a longwall gob," Journal of Natural Gas Science and Engineering, vol. 36, pp. 1312-1325, 2015.
[16] F. An, Z. Wang, H. Yang et al., "Application of directional boreholes for gas drainage of adjacent seams," International Journal of Rock Mechanics and Mining Sciences, vol. 90, pp. 3542, 2016.

[17] E.P.A, Methane emissions from abandoned coal mines in the United States, United States: EPA 430-R-04-001, 2004.

[18] I. Leifer and K. Wilson, "The tidal influence on oil and gas emissions from an abandoned oil well: Nearshore Summerland, California," Marine Pollution Bulletin, vol. 54, no. 9, pp. 14951506, 2007.

[19] V. Palchik, "Time-dependent methane emission from vertical prospecting boreholes drilled to abandoned mine workings at a shallow depth," International Journal of Rock Mechanics and Mining Sciences, vol. 72, pp. 1-7, 2014.

[20] Q.-T. Hu and H.-T. Sun, "Graded optimization design method on surface gas drainage borehole," Journal of the China Coal Society, vol. 39, no. 9, pp. 1907-1913, 2014.

[21] J. Liu, H. Sun, and Q. Hu, "Surface borehole synthesis tension deformation fracture time-space rule," International Journal of Mining Science and Technology, vol. 22, no. 4, pp. 465-470, 2012.

[22] L. Yuan, H. Guo, P. Li, Y.-P. Liang, and B.-C. Liao, "Theory and technology of goaf gas drainage with large- diameter surface boreholes," Journal of the China Coal Society, vol. 38, no. 1, pp. $1-8,2013$.

[23] H. Wang, Y. Jiang, S. Xue et al., "Assessment of excavation damaged zone around roadways under dynamic pressure induced by an active mining process," International Journal of Rock Mechanics and Mining Sciences, vol. 77, pp. 265-277, 2015.

[24] Z. Zhu, Q. Wang, and Q. Wu, "On the examination of the Darcy permeability of soft fibrous porous media; new correlations," Chemical Engineering Science, vol. 173, pp. 525-536, 2017.

[25] Q. Li, B. Lin, C. Zhai et al., "Variable frequency of pulse hydraulic fracturing for improving permeability in coal seam," International Journal of Mining Science and Technology, vol. 23, no. 6, pp. 847-853, 2013.

[26] W. Wang, X. Li, B. Lin, and C. Zhai, "Pulsating hydraulic fracturing technology in low permeability coal seams," International Journal of Mining Science and Technology, vol. 25, no. 4, article 549, pp. 681-685, 2015.

[27] J. Xu, C. Zhai, and L. Qin, "Mechanism and application of pulse hydraulic fracturing in improving drainage of coalbed methane," Journal of Natural Gas Science and Engineering, vol. 40, pp. 79-90, 2017.

[28] A. Liu, X. Fu, K. Wang, H. An, and G. Wang, "Investigation of coalbed methane potential in low-rank coal reservoirs - Free and soluble gas contents," Fuel, vol. 112, pp. 14-22, 2013. 

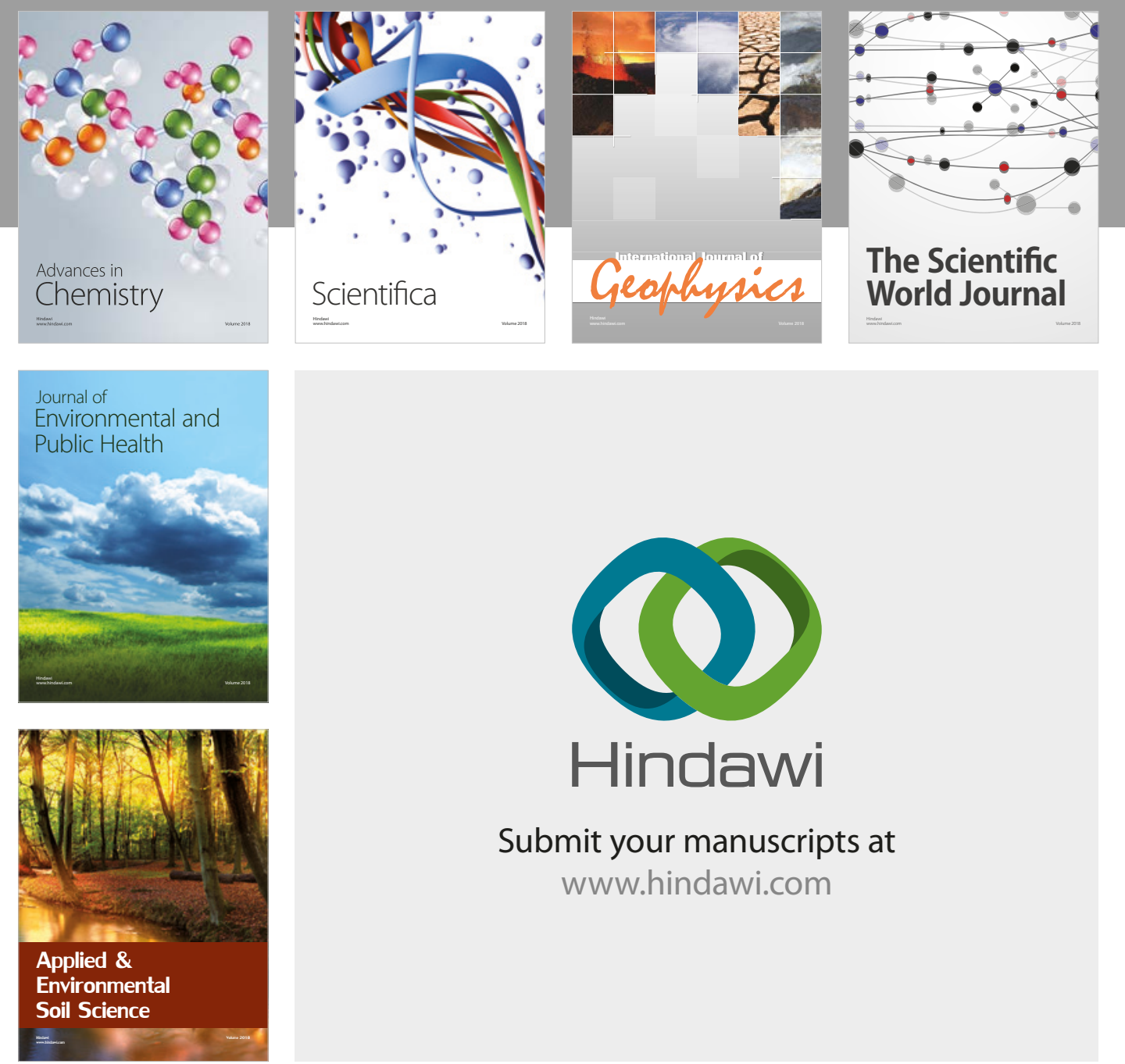

The Scientific

\section{World Journal}
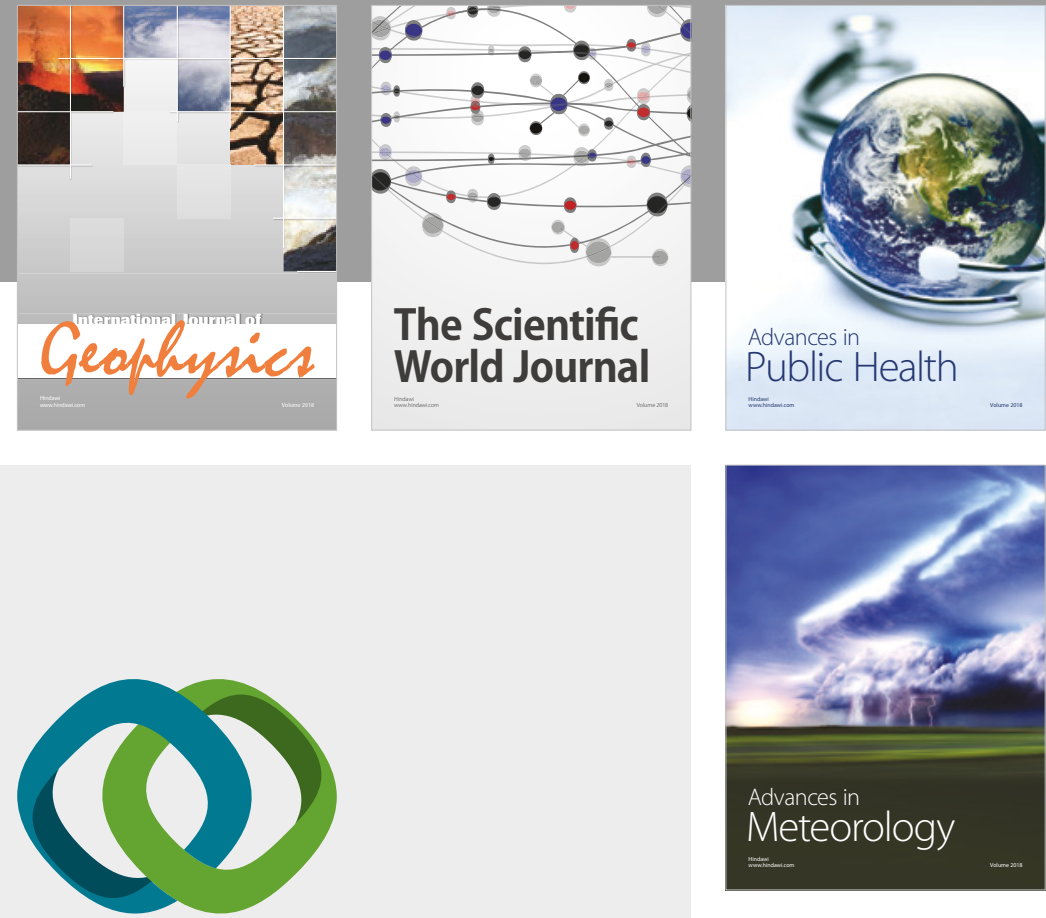

Advan

Public Health

\section{Hindawi}

Submit your manuscripts at

www.hindawi.com
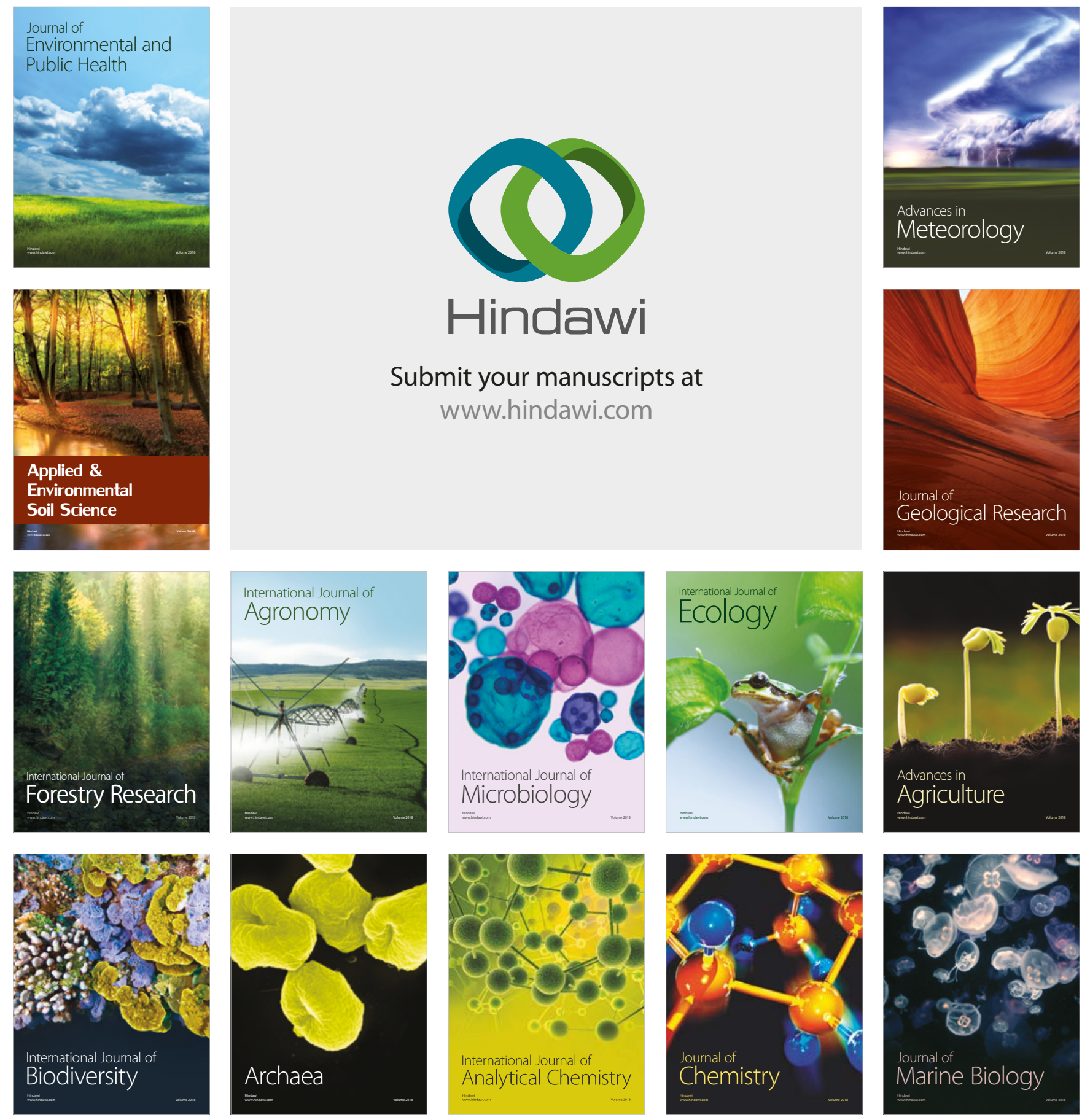